\title{
Diversity of species in making up Nike fish schools and a new record of Eleotris melanosoma in Tomini Paguyaman Bay, Gorontalo, Indonesia
}

\author{
FEMY M SAHAMI", SITTY AINSYAH HABIBIE \\ Faculty of Fisheries and Marine Sciences, Universitas Negeri Gorontalo. Jl. Jend. Sudirman No. 6, Gorontalo 96128, Gorontalo, Indonesia. \\ Tel.: +62-435-821125, Fax.: +62-435-821752. `email: femysahami@ung.ac.id
}

Manuscript received: 5 September 2021. Revision accepted: 24 November 2021

\begin{abstract}
Sahami FM, Habibie SA. 2021. Diversity of species in making up Nike fish schools and a new record of Eleotris melanosoma in Tomini Paguyaman Bay, Gorontalo, Indonesia. Biodiversitas 22: 5459-5467. Several estuaries in the waters of Tomini Bay are reported as the primary location for Nike fishing in Gorontalo; one of which is Paguyaman Bay. However, scientific information on Nike fish in the Tomini Bay waters is currently limited in Gorontalo Bay. The present study aims to determine the diversity of spe cies in making up the Nike fish schools in Paguyaman Bay and show the types of constituent species whose distribution in Gorontalo waters has never been reported. A total of 1773 samples of Nike fish were collected from the sea to the estuary of Paguyaman Bay in one period of their emergence on April 8-10, 2021. The species were grouped based on the melanophore pattern's similarity and then analyzed morphometrically. The molecular identification of COI mitochondrial DNA was performed on species with different morphological appearances from those found in Gorontalo Bay. The Discriminant Function Analysis (DFA) indicated that the main distinguishing character of morphometrics is body depth. The morphological results suggested that the Nike fish schools in Paguyaman Bay consisted of seven species, four genera, and two families, i.e., Sicyopterus longifilis, S. parvei, S. cynocephalus, Stiphodon semoni, Belobranchus segura, B. belobranchus, and Eleotris melanosoma. The first finding of E. melanosoma as a species making up the Nike fish schools in Paguyaman Bay was a new variant of the distribution of this species in Gorontalo waters and confirmed using morphology and molecular analysis. Further, based on the species composition, Nike fish schools in the waters of Paguyaman Bay show a typical species dominance trend during the recruitment process returning to freshwater, i.e., S. longifilis (52\%) on the first day, Belobranchus segura (63.27\%) on the second day, and Stiphodon semoni (83.43\%) on the third day.
\end{abstract}

Keywords: Belobranchus, Eleotridae, Gobiidae, Sicydiinae, Sicyopterus, Stiphodon

\section{INTRODUCTION}

Tomini Bay is Indonesia's largest bay intersecting related with 14 districts in three provinces of Sulawesi, namely North Sulawesi, Central Sulawesi, and Gorontalo. Nike (local name, pronounced nee-K) are among the essential fishery commodities in Tomini Gorontalo Bay communities. They consist of amphidromous goby schools in the pelagic to juvenile larval stages in the recruitment process from marine waters to freshwater, and their emergence is seasonal. Their hatched embryos are carried by the river flow to the sea and develop as pelagic larvae before being recruited, returning to rivers and growing as adults and spawn (Thuesen et al. 2011; Yamasaki et al. 2011; Taillebois et al. 2012; Iida et al. 2017; Mennesson et al. 2019; Mennesson and Keith 2020; Sahami and Habibie 2020). The diversity of species making up Nike fish schools (post-larva goby) in Gorontalo waters is one of the essential studies that should be conducted continuously, considering the high economic value potential as a food commodity in Gorontalo with an $\mathrm{R} / \mathrm{C}$ ratio of 2.68 (economically feasible) (Wolok et al. 2019). As of today, approximately 1120 species from 30 genera in the goby group are described. The goby group plays a vital role in ichthyofauna diversity with a wide area distribution among many species. These fish groups are dominantly found in the eastern part of Indonesia, with high species diversity
(Tweedley et al. 2013; Miesen et al. 2016; Hadiaty and Sauri 2017; Nurjirana et al. 2020).

Geographically, there are several rivers in Gorontalo which empty into Tomini Bay. Some of these river estuaries are important locations for Nike fish catching in Gorontalo, including Gorontalo Bay and Paguyaman Bay (Salam et al. 2016). Numerous studies have reported Nike fish in Gorontalo Bay (Olii et al. 2017; Olii et al. 2019; Sahami et al. 2019a; Sahami et al. 2019b; Pasisingi et al. 2020a; Sahami et al. 2020). Meanwhile, scientific data on Nike fisheries in the Paguyaman Bay estuary are not widely observed. Paguyaman Bay is part of the Tomini Bay areas located on the border of Girisa Village, Paguyaman Sub-district, Boalemo District with Bilato Village, Boliyohuto Sub-district, Gorontalo District. The bay is the estuary of the Paguyaman River, whose watershed flows across three districts, i.e., Gorontalo, Boalemo, and Pohuwato. The presence of the Paguyaman watershed as the second-largest watershed in Gorontalo and directly intersecting with three administrative districts draws the interest to observe the Paguyaman Bay estuary.

The demographic information, such as life history at early stages, recruitment, migration patterns, and other biological characteristics, is crucial for managing fish populations (Habibie et al. 2015). Information about the identification and composition of species is also essential in the management process. Hence, the management can be 
carried out effectively. As currently reported, the types of species making up the Nike fish schools in the waters of Gorontalo Bay consist of nine species i.e., Sicyopterus pugnans, S. longifilis, S. lagocephalus, S. cynocephalus, $S$. parvei, Bunaka gyrinoides, Belobranchus segura, B. belobranchus, and Stiphodon semoni (Olii et al. 2019; Sahami et al. 2019b; Sahami et al. 2020). Although the goby is widely distributed in tropical Indo-Pacific waters (Keith et al. 2015; Lord et al. 2019), species diversity in each water location needs to be examined further. Therefore, the present study aims to find out the diversity of species making up the Nike fish schools in Paguyaman Bay and reveal the types of constituent species whose distribution in the waters of Gorontalo Bay has never been reported. The present work is also expected to provide significant scientific information for Nike fish resource management in Paguyaman Bay and to support and optimize Nike fisheries in the Gorontalo waters.

\section{MATERIALS AND METHODS}

\section{Sampling}

The samples of Nike fish were collected in Paguyaman

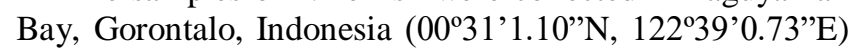
(Figure 1) for three days in one period of emergence on April 8-10, 2021. This period was the only emergence period of Nike fish in Paguyaman Bay from January to May 2021. A total of 150 grams of Nike fish samples were taken from the fishermen. Nike fishing in Paguyaman Bay typically used Dudayahu and Totaluo fishing gear with excellent mesh designed for operation in shallow water
(Salam et al. 2016). Nike's schooling migration (Sahami et al. 2020) made it easy for fishers to catch this fish specifically. The catching process was carried out in the early morning. The samples were then brought to the Hydrobioecology and Biometrics Laboratory, Faculty of Fisheries and Marine Sciences, Gorontalo State University, for analysis. After that, the samples were grouped, identified, referred to Sahami et al. (2019b) and Sahami et al. (2020) methods, photographed for morphometric analysis, and calculated the number per group. Fish samples with different melanophore patterns from Nike fish that have been identified in the Gorontalo Bay (Sahami et al. 2019b; Sahami et al. 2020) were referred to as a new variant. Identifying a new variant was carried out genetically by placing five individuals into a sample bottle that already contained a $95 \%$ ethanol solution.

\section{Morphometric characters}

Ten morphometric characters of Nike fish referring to Sahami et al. (2020) (Figure 2, Table 1) were measured using the imageJ application with an accuracy of $0.001 \mathrm{~cm}$.

Each measured morphometric character datum was then standardized following the allometric formula according to Elliott et al. (1995) as follows:

$$
\mathrm{M}_{\mathrm{adj}}=\mathrm{M}\left(\mathrm{L}_{\mathrm{s}} / \mathrm{L}_{0}\right)^{\mathrm{b}}
$$

$\mathbf{M}_{\mathrm{adj}}$ is the standardized morphometric data, $\mathbf{M}$ is the measured morphometric data, $\mathrm{L}_{0}$ is the total length of fish, $\mathrm{L}_{\mathrm{s}}$ is the average total length, parameter $b$ is the slope of $\log$-linear curve $\mathrm{M}$ to $\log \mathrm{L}_{0}$ of all data.

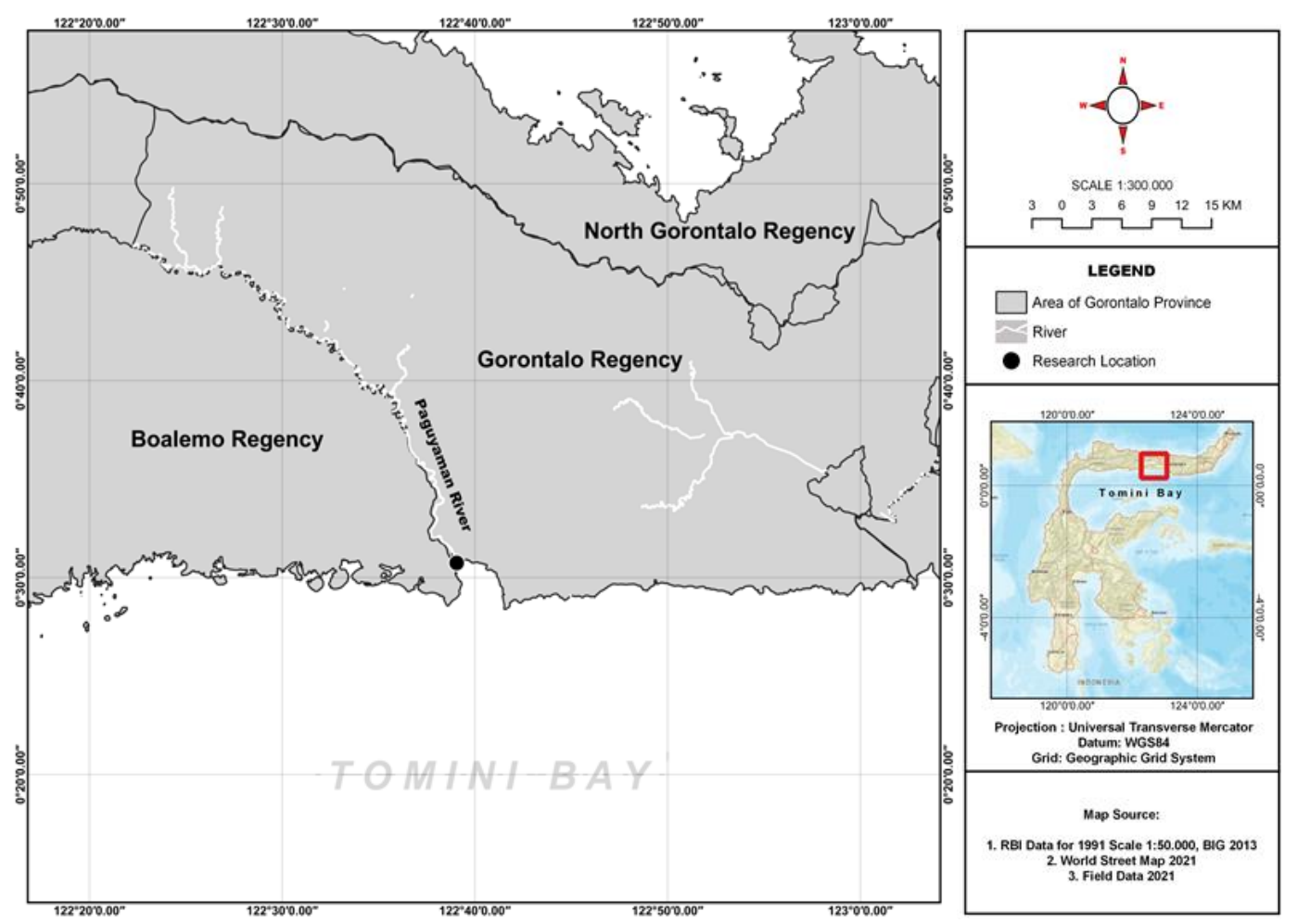

Figure 1. Research site map in Paguyaman Bay, Gorontalo, Indonesia 


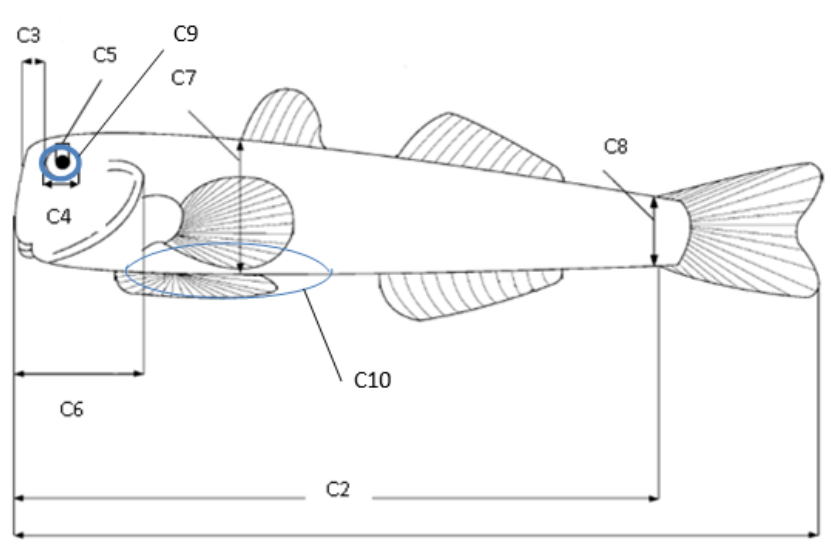

C1

Figure 2. Morphometric characters of Nike fish (Sahami et al. 2020)

Table 1. Morphometric characters of Nike fish (Sahami et al. 2020)

\begin{tabular}{cl}
\hline Code & \multicolumn{1}{c}{ Morphometric characters } \\
\hline C1 & Total length (TL) \\
C2 & Standard length (SL) \\
C3 & Preorbital length (PL) \\
C4 & Eye diameter (ED) \\
C5 & Eye lens diameter (EL) \\
C6 & Head length (HL) \\
C7 & Body depth (BD) \\
C8 & Peduncle depth (PD) \\
C9 & Eye area (EA) \\
C10 & Yolk sac area (YS) \\
\hline
\end{tabular}

\section{DNA extraction, PCR amplification, and sequencing}

The target gene for molecular analysis was the mitochondrial Deoxyribonucleic acid (DNA) Cytochrome Oxidase Subunit 1 (COI) gene. COI gene is the best resolution of the intraspecific level than other core genes (Bellagamba et al. 2015; Hubert et al. 2015; Rodrigues et al. 2017; Bingpeng et al. 2018; Roesma et al. 2018, Yulianto et al. 2020). In addition, mitochondrial COI genes are also widely and reliably utilized to identify species in the goby group (Jeon et al. 2012; Viswambharan et al. 2013; Laskar et al. 2016; Lejeune et al. 2016; Wang et al. 2017; Linh et al. 2018; Olii et al. 2019; Sahami et al. 2019a; Sahami et al. 2019b; Pasisingi et al. 2020b; Roesma et al. 2020; Sahami et al. 2020). Following the protocol kit, 20 grams of fish meat tissue of a new variant individual was isolated using Qiagen Tissue and blood extraction kits for genetic analysis. The mitochondrial DNA COI gene was further amplified using the primer pair FishF1 5'TCAACCAACCACAAAGACATTGGCAC-3' and FishR1 5'-TAGACTTCTGGGTGGCCAAAGAATCA-3' (Ward et al. 2005). Samples were amplified at pre-denaturation temperature of $94^{\circ} \mathrm{C}$ for five minutes, denaturation at $94^{\circ} \mathrm{C}$ for 30 seconds, annealing at $50^{\circ} \mathrm{C}$ for 30 seconds, extension at $72^{\circ} \mathrm{C}$ for 30 seconds, and final extension at $72^{\circ} \mathrm{C}$ for 7 minutes. This Polymerase Chain Reaction (PCR) process lasted for 38 cycles.

\section{Data analysis}

The DNA samples were amplified and electrophoresed, and then the gene was sequenced using the Dideoxy Sanger Termination Method. Contig was done for the nucleotide sequences. After that, the results were matched with the data available in the GenBank database (www.ncbi.nlm.nih.gov) through the Basic Local Alignment Search Tool (BLAST). The phylogenetic tree was arranged by aligning the DNA sequences of identified samples with some DNA of gobies (accession number KF489573, KU232392, KU692483, KU692484, and KU692490) and the species of Nike fish schools in Gorontalo Bay (accession number MN069306, MN069307, MN069308, MT706639, MT706640, MT706641, MT706720, MT706721, MT706722, MT706723, MT706724, MT706725, MT706726, and MT706791) available in the GenBank database using the Maximum Likelihood 1,000 bootstrap method on MEGAX software (Kumar et al. 2018). The results of genetic identification were further confirmed morphologically, referring to Maeda and Tachihara (2005). Furthermore, the Discriminant Function Analysis (DFA) (Landau and Everit 2004) was performed to determine the main distinctive characters among species using IBM SPSS Statistics 25.

\section{RESULTS AND DISCUSSION}

New variant of species that makes up the Nike fish schools

The emergence of Nike fish in Paguyaman Bay does not have a regular pattern as in Gorontalo Bay, in which the periodization occurs almost every month. In 2021, Nike fish in Paguyaman Bay first appeared in April with a 3-day emergence period (April 8-10, 2021) since observed from January and no longer appeared in May. Based on the NCBI database referring to the mitochondrial COI gene sequencing, a new melanophore pattern species was identified as Eleotris melanosoma (Figure 3). The nucleotide sequence of E. melanosoma was listed in the NCBI database with accession number MZ401475.

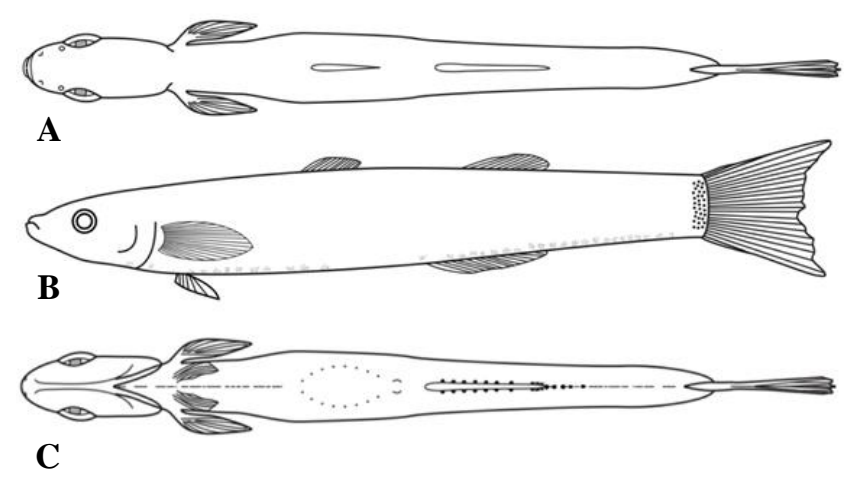

Figure 3. Pelagic larvae of Eleotris melanosoma in Paguyaman Bay, Gorontalo, Indonesia. A. Dorsal view; B. Lateral view; C. Ventral view 
The caught species of E. melanosoma have a standard length of 19.05-20.04 mm with an average standard length of $19.55 \mathrm{~mm}$. These species have a transparent body, an elongated and compressed body shape, and no scales. In addition, the body fins are not yet fully developed, pelvic fins are separated, and the caudal fin tends to form emarginate. There are no melanophore spots distributed from head to body, and few melanophore spots accumulated at the base of the caudal fin. These morphological features correspond to the morphology of the pelagic larvae of E. melanosoma as reported by Maeda and Tachihara (2005).

The results of the alignment of the DNA sequences of E. melanosoma with the DNA sequences of the species that make up the Nike fish school in Gorontalo Bay and several Eleotris species available in the NCBI Genbank are displayed through a phylogenetic tree (Figure 4). The analysis results show that E. melanosoma is closely related to Eleotris fusca and is in the same monophyletic clade as Belobranchus segura, B. belobranchus, and Bunaka gyrinoides. The similarity of the clades in these five species is because they are members of the Eleotridae family, although it is clear that there are sub-clades based on the similarity of the genus in this clade. Furthermore, the second monophyletic clade is the family clade Gobiidae which includes the species Stiphodon semoni, Sicyopterus longifilis, S. lagocephalus, S. parvei, and S. cynocephalus. The second monophyletic clade also groups the species in the genus Sicyopterus in the same sub-clade and separated from the genus Stiphodon.

\section{Composition of species}

A total of 1773 specimens were observed as constituents of Nike fish schools in Paguyaman Bay for three days of emergence in April 2021. Two families, i.e., Gobiidae and Eleotridae, were recorded to make up Nike fish schools. The Gobiidae family consisted of four species, i.e., Sicyopterus longifilis, S. parvei, S. cynocephalus, and Stiphodon semoni. Meanwhile, the Eleotridae family consisted of three species, namely Belobranchus segura, B. belobranchus, and Eleotris melanosoma. Among seven species, three species in family Gobiidae, i.e., S. longifilis, S. parvei, and Stiphodon semoni were observed as species that made up Nike fish schools during their emergence. The species was consistently observed in considerable numbers (S. longifilis), whereas B. segura was observed only on the second day. On the third day of emergence, $B$. belobranchus and E. melanosoma were observed. S. semoni is the most abundant species observed (34.07\%), meanwhile $S$. parvei and B. segura are at least $0.003 \%$. Based on the species composition, species dominance was different each day. On the first, second, and third day, the school of Nike fish was dominated by $S$. longifilis, Belobranchus segura, and Stiphodon semoni with a composition value of $(52 \%), 63.27 \%$, and $83.43 \%$, respectively (Figure 5).

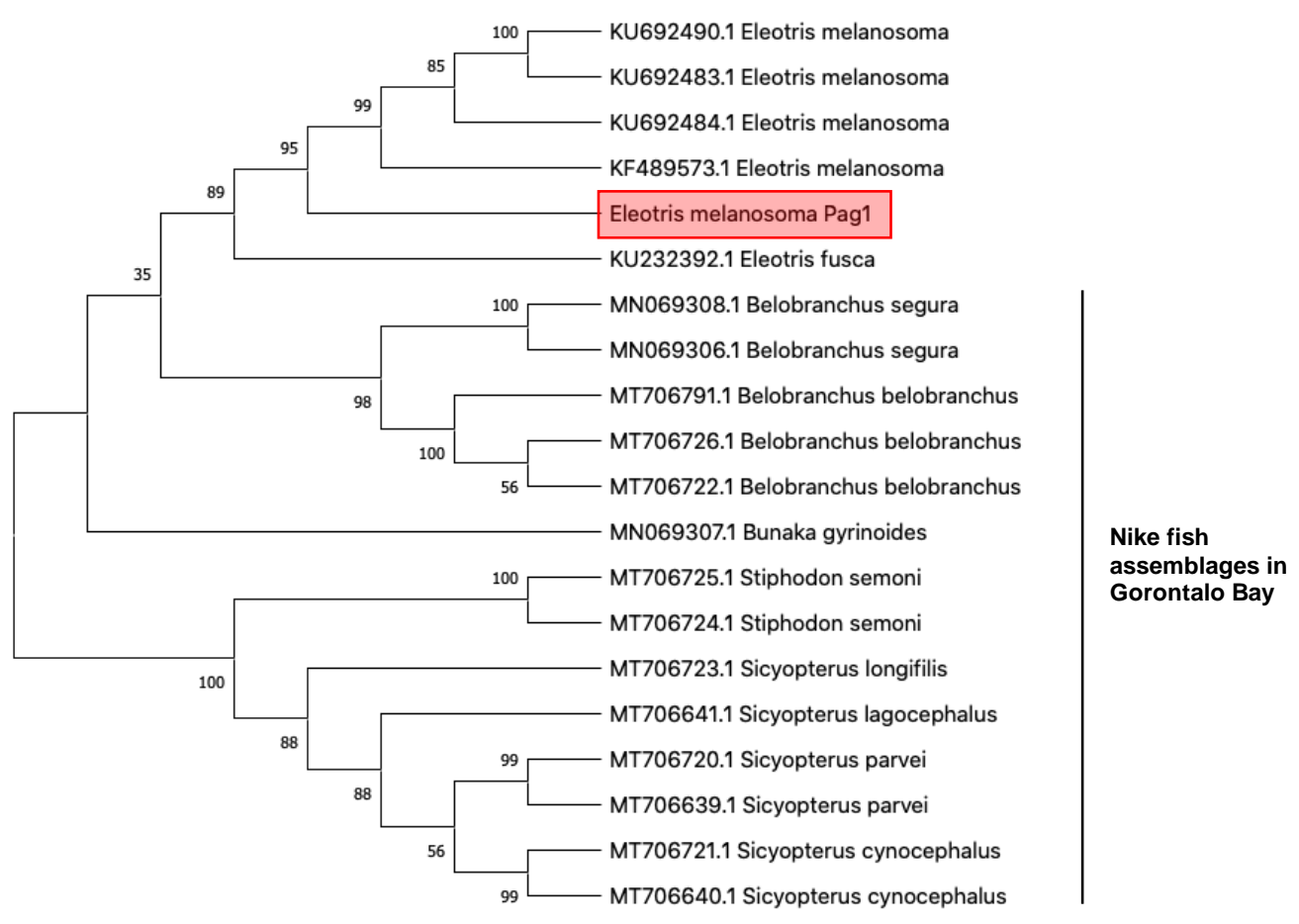

Figure 4. Phylogenetic tree of Eleotris melanosoma with several species of gobies and composers of Nike fish in Gorontalo Bay waters, Indonesia available in the NCBI database 


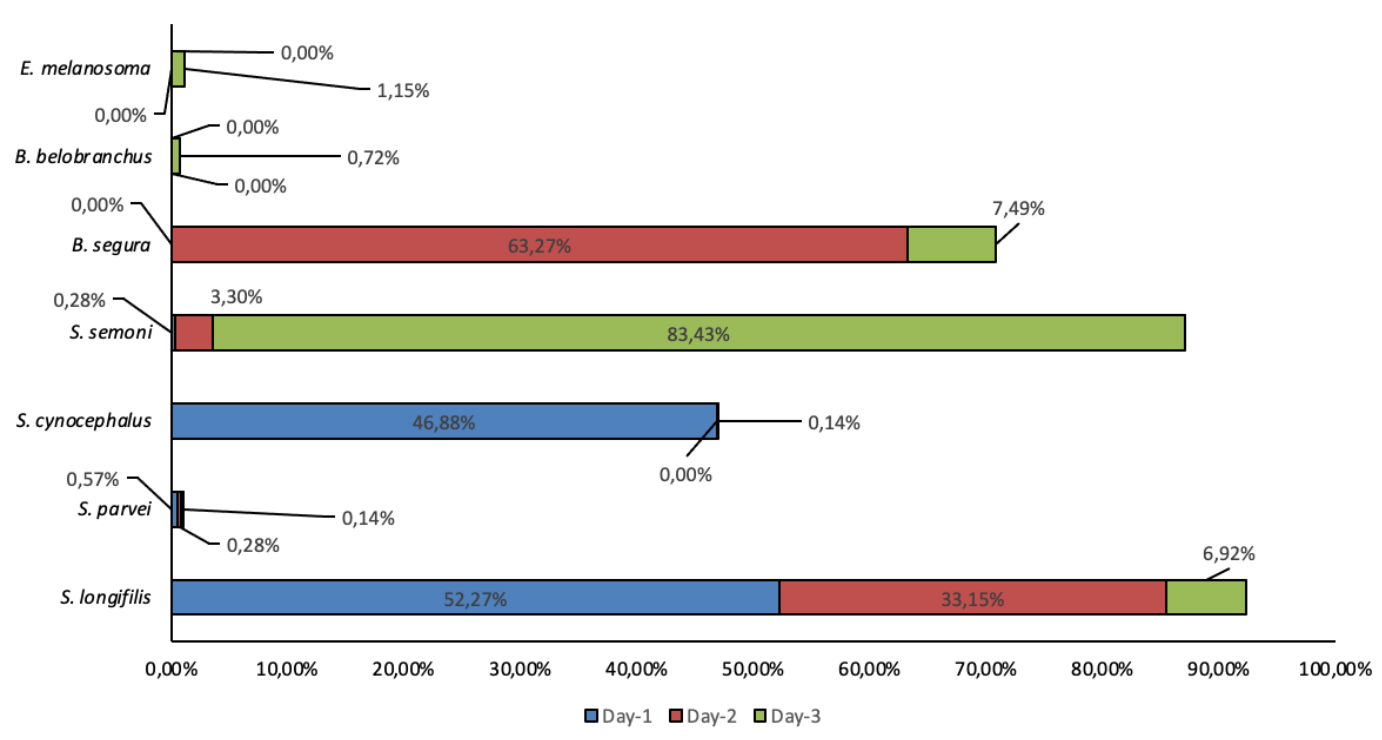

Figure 5. Nike fish schools composition in Paguyaman Bay waters, Gorontalo, Indonesia

\section{Size distribution and morphometric characters}

The total length of the collected Nike fish ranged from 1.523 to $3.572 \mathrm{~cm}$ (Table 2). The Stiphodon semoni (Gobiidae) and S. parvei (Gobiidae) species have the smallest and biggest size. The species with the widest size range is $S$. cynocephalus $(2.422-3.572 \mathrm{~cm})$, and the species with the smallest size range is B. belobranchus $(2.290$ $2.403 \mathrm{~cm}$ ).

The morphometric characters can be used in taxonomy as early identification in fisheries science (Sara et al. 2016). The summary morphometric characters data standardized following the allometric formula Elliott et al. (1995) is presented in Table 3. Moreover, the analysis of discriminant function is presented in Figure 6. Two discriminant functions are able to explain $67.3 \%$ and $24.5 \%$ of the total variance of morphometric characters. Based on this work, the C7 character (body depth) is the main distinctive character of the Nike population in Paguyaman Bay. The tendency of Nike fish formation in Paguyaman Bay is clearly shown by a group of centroid in Figure 6 . The species of Sicyopterus longifilis, S. cynocephalus, S. parvei, and $S$. semoni tend to overlap and adjacent since four species are members of the Gobiidae family. Furthermore, Belobranchus segura and Belobranchus belobranchus are the most related spots because both species are from the same genus of Belobranchus. The Eleotris melanosoma, although was distributed in separate areas, is close to B. belobranchus because both species are members of the Eleotridae family. In general, species identification through canonical discriminant diagrams (Figure 6) is in line with the phylogenetic tree shown in Figure 4.

Table 2. Size range of each species making up Nike fish schools in Paguyaman Bay waters, Gorontalo, Indonesia

\begin{tabular}{lcc}
\hline \multicolumn{1}{c}{ Species } & $\begin{array}{c}\text { Mean size } \\
(\mathbf{c m})\end{array}$ & $\begin{array}{c}\text { Size range } \\
(\mathbf{c m})\end{array}$ \\
\hline Sicyopterus longifilis & 2.666 & $2.262-3.044$ \\
Sicyopterus parvei & 3.036 & $2.831-3.403$ \\
Sicyopterus cynocephalus & 2.775 & $2.422-3.572$ \\
Stiphodon semoni & 2.137 & $1.523-2.586$ \\
Belobranchus segura & 2.311 & $2.005-2.638$ \\
Belobranchus belobranchus & 2.347 & $2.290-2.403$ \\
Eleotris melanosoma & 2.377 & $2.304-2.448$ \\
\hline
\end{tabular}

Table 3. Morphometric character data of Nike fish schools in Paguyaman Bay waters, Gorontalo, Indonesia

\begin{tabular}{|c|c|c|c|c|c|c|c|c|c|}
\hline \multirow{2}{*}{ Species } & \multicolumn{9}{|c|}{ Unit of characters (Mean $(\mathbf{c m}) \pm$ SD) } \\
\hline & SL & PL & ED & EL & HL & BD & PD & EA & YS \\
\hline S. longifilis & $2.054 \pm 0.05$ & $0.111 \pm 0.02$ & $0.136 \pm 0.02$ & $0.060 \pm 0.01$ & $0.518 \pm 0.04$ & $0.381 \pm 0.03$ & $0.208 \pm 0.02$ & $0.013 \pm 0.00$ & $0.026 \pm 0.00$ \\
\hline S. parvei & $2.086 \pm 0.03$ & $0.128 \pm 0.03$ & $0.133 \pm 0.02$ & $0.062 \pm 0.01$ & $0.535 \pm 0.03$ & $0.376 \pm 0.01$ & $0.205 \pm 0.01$ & $0.012 \pm 0.00$ & $0.031 \pm 0.01$ \\
\hline S. cynocephalus & $2.043 \pm 0.05$ & $0.114 \pm 0.02$ & $0.133 \pm 0.02$ & $0.057 \pm 0.01$ & $0.521 \pm 0.05$ & $0.375 \pm 0.03$ & $0.203 \pm 0.02$ & $0.012 \pm 0.00$ & $0.029 \pm 0.01$ \\
\hline S. semoni & $2.062 \pm 0.05$ & $0.104 \pm 0.02$ & $0.129 \pm 0.02$ & $0.056 \pm 0.01$ & $0.489 \pm 0.04$ & $0.343 \pm 0.04$ & $0.188 \pm 0.03$ & $0.012 \pm 0.00$ & $0.020 \pm 0.01$ \\
\hline B. segura & $2.094 \pm 0.04$ & $0.126 \pm 0.02$ & $0.129 \pm 0.02$ & $0.061 \pm 0.01$ & $0.556 \pm 0.05$ & $0.392 \pm 0.03$ & $0.221 \pm 0.02$ & $0.012 \pm 0.00$ & $0.035 \pm 0.01$ \\
\hline B. belobranchus & $2.051 \pm 0.05$ & $0.140 \pm 0.03$ & $0.128 \pm 0.02$ & $0.067 \pm 0.01$ & $0.579 \pm 0.03$ & $0.325 \pm 0.01$ & $0.213 \pm 0.01$ & $0.015 \pm 0.00$ & $0.021 \pm 0.00$ \\
\hline E. melanosoma & $2.033 \pm 0.02$ & $0.123 \pm 0.01$ & $0.129 \pm 0.00$ & $0.058 \pm 0.01$ & $0.535 \pm 0.04$ & $0.280 \pm 0.02$ & $0.208 \pm 0.01$ & $0.012 \pm 0.00$ & $0.013 \pm 0.00$ \\
\hline
\end{tabular}



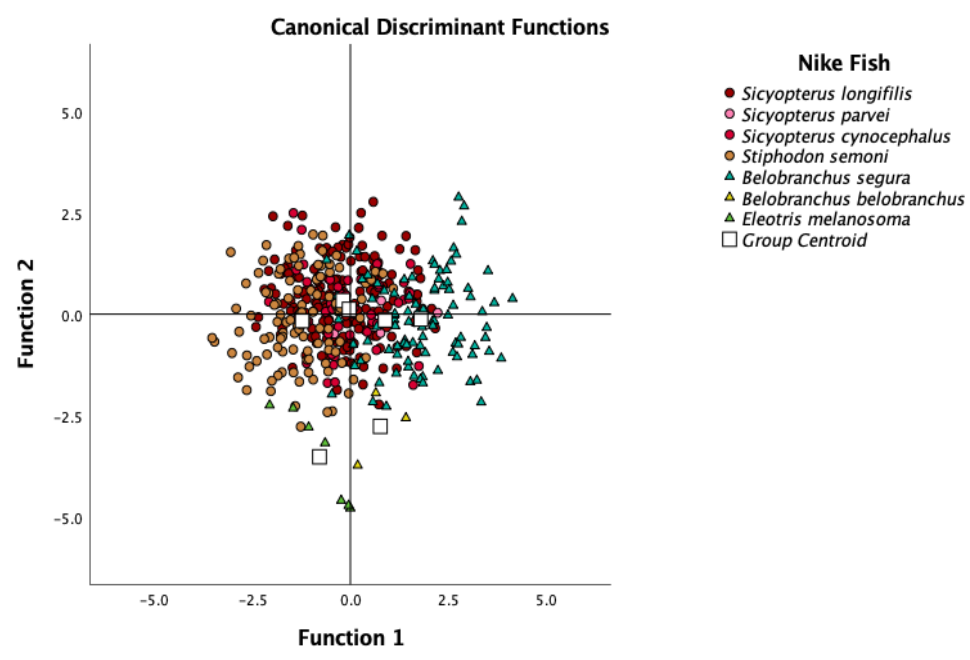

Figure 6. Diagram of the canonical discriminant function of Nike fish in Paguyaman Bay waters, Gorontalo, Indonesia

\section{Discussion}

The species that make up the Nike fish schools in Paguyaman Bay consist of seven species, fewer than the nine species reported in Gorontalo Bay (Olii et al. 2019; Sahami et al. 2019b; Sahami et al. 2020). Two species of gobies are $S$. pugnans and Bunaka gyrinoides are not observed as the constituents of Nike fish schools in Paguyaman Bay. However, the present study reports a new record of the distribution of $E$. melanosoma. Identifying $E$. melanosoma as one of the species making up the Nike fish schools in Paguyaman Bay based on molecular and morphological analysis is a new record of the distribution of this species in Gorontalo waters. A total of eight species of E. melanosoma were caught as the constituents of the Nike fish schools in Paguyaman Bay when they began to approach the river estuary on the third day of their emergence.

The E. melanosoma species is one of the three main species of Eleotris reported to be distributed in the IndoPacific waters. Two of the other species are E. fusca and E. acanthopoma (Maeda et al. 2011; Mennesson et al. 2019; Subchan et al. 2020). The other Eleotris species can continue to be recorded when more studies focus on this topic in more locations in Indo-Pacific waters. As reported by Maeda and Tachihara (2005), the pelagic and newly settled larvae of $E$. fusca show a larger body size than $E$. melanosoma and E. acanthopoma. Eleotris pelagic larvae migrate to river areas by utilizing the rising tides at night. E. melanosoma and E. acanthopoma settle at the upper end of the tidal affected area, meanwhile E. fusca migrates to freshwater upstream against river water flow currents.

In terms of size, the species of E. melanosoma caught in Paguyaman Bay (average standard length $19.55 \mathrm{~mm}$ ) should in the newly settled larval stage based on research Maeda and Tachihara (2005) in the Teima River estuary area, Okinawa Island, with increasingly numerous visible body pigmentation and completely pigmented caudal fin with no distal border. However, the morphology of $E$. melanosoma species in the site area still characterizes the morphology of the pelagic larval stage, with the most conspicuous feature and no melanophore spots on its sides. Such a difference in feature is due to the difference in the aquatic habitat area (Habibie et al. 2018). Besides, the tropical area's stable temperature throughout the year has no significant effect on the fish growth rate (Habibie et al. 2015). The pelagic to juvenile larval stages of $E$. melanosoma species were also recorded in the estuary area of the Teima River, Okinawa Island (Maeda and Tachihara 2005) and Sri Lankan waters estuary (Batuwita et al. 2017). Meanwhile, the adult species were found in the fresh waters of Japan (Maeda et al. 2011); rivers on the Buton and Kabaena Islands (Tweedley et al. 2013); Opak River, Yogyakarta (Djumanto et al. 2013); freshwater of Sri Lanka (Batuwita et al. 2017); freshwater of West Sulawesi (Nurjirana et al. 2020); and Sanenrejo and Wonoasri River Resorts (Subchan et al. 2020).

Among amphidromous fish, the Eleotridae and Gobiidae (Teleostei: Gobioidei) are the most common families discovered in estuaries and freshwater of the IndoPacific area. The Eleotrid species mostly inhabits the lower and middle parts of freshwater flows characterized by waiting for prey (Mennesson et al. 2015; Mennesson and Keith 2020). Eleotris pelagic larvae morphological features are transparent and compressed bodies, conspicuous swim bladder, and emarginate caudal fin (Maeda and Tachihara 2005). On the other hand, the adult species has a large blunt head, torpedo-shaped body, rounded caudal fin, prominent lower jaw, discrete fin ventral, has no lateral line on the sides of the body, and inconspicuous body color, mostly light brown, dark brown, or olive with some dazzled metallic (Murdy and Hoese 2002; Batuwita et al. 2017; Mennesson and Keith 2020). In contrast, the species of the Gobiidae family are active swimmers. They have pelvic fins that are fused and form a sucking disc to attach themselves to the substrate while actively swimming against currents towards the upstream (Keith 2003; Taillebois et al. 2014). The genus Sicyopterus uses its 
mouth as a secondary sucking disc that allows this genus to access areas upstream of waterfalls quickly (Keith 2003).

The Nike fish both in Paguyaman Bay and Gorontalo Bay is an amphidromous species. As an amphidromous species, the adults are hatch in rivers, then larvae flow downstream (sea) and grow in coastal or offshore marine habitats, then recruitment occurs in rivers (Yamasaki et al. 2011; Taillebois et al. 2012; Iida et al. 2017; Mennesson et al. 2019; Mennesson and Keith 2020; Sahami and Habibie 2020). The amphidromous larvae passively follow the river water currents after hatching in the afternoon and reach the estuary in the middle of the night (Maeda and Tachihara 2010). Some amphidromous gobies, especially subfamily Sicydiinae, often hatch less than 48 hours after fertilization, so that the larvae are carried downstream with lots of yolks, and the risk of starvation is minimized (McDowall 2009). One of the strategies employed is spawning in river areas near the estuary to shorten the larval drift time in freshwater environments (Lagarde et al. 2017).

The emergence period of Nike fish schools in the bay and moving into the estuary is pre-colonization phase. In this phase, gobies' post-larvae will swarm and prefer to swim near the shoreline because the water flowing is slower and can even be reversed by tides or waves (Keith et al. 2008). Making schools is a gobies strategy to avoid predators besides finding food (Keith 2003). The species' diversity and sizes making up the fish schools are strongly influenced by the characteristics of the species, season, and hatching time. According to Taillebois et al. (2012), the duration of the pelagic larvae is not the only factor determining species distribution; It is most likely interactions between larval behavior, environment, currents, and substrate preferences. Apart from these factors mentioned previously, the larger fish larvae possibly result from earlier hatching compared to smaller fish larvae (Mennesson et al. 2015). In addition, the rainy season will support the newly hatched larvae drifting into the sea faster (Keith 2003).

According to Landau and Everit (2004), the discriminant analysis determines the main distinctive character among populations. The present study confirmed that body depth is the main distinguishing characteristic among Nike fish populations in Paguyaman Bay. It is contrary to the main distinctive character of Nike populations in Gorontalo Bay, i.e., head length (Sahami et al. 2020). The difference in the main distinguishing characters between the two locations since the gobies species are able to develop various morphological specificities as adaptations strategy for their environment (Gani et al. 2019; Roesma et al. 2020). Thus, the different backgrounds are able to affect the morphological characters of species in their environment. Populations in different environments are likely to have different population structures. Differences in population structure will influence population size, which can be observed through differences in morphometric and meristic characters (Aisyah and Syarif 2018).

Based on their species composition, the Nike fish schools in Paguyaman Bay waters indicate a trend of typical species dominance every day during the recruitment back to freshwater. On the first day of their emergence in Paguyaman Bay, the Nike fish schools were composed of species in the Gobiidae family and dominated by $S$. longifilis $(52 \%)$. Furthermore, the species were dominated by Belobranchus segura $(63.27 \%)$ on the second day and Stiphodon semoni $(83.43 \%)$ on the third day when the fish schools started to enter the river estuary. This research is the first finding related to the pattern of Nike fish emergence and the composition of its constituent species in Paguyaman Bay. The emergence period of Nike fish in this location, which is not a regular pattern such as in Gorontalo Bay, limits the research sample. Therefore, species composition variation in the emergence period requires further studies. In general, the gobies adapt mostly to aquatic habitats, although with various abundance degrees (Gani et al. 2019).

In conclusion, the Nike fish schools in Paguyaman Bay consist of seven species, four genera, and two families, i.e., Sicyopterus longifilis, S. parvei, S. cynocephalus, Stiphodon semoni, Belobranchus segura, B. belobranchus, and Eleotris melanosoma. Species with the new melanophore pattern is E. melanosoma, confirmed through morphological and molecular analysis. A new variant of $E$. melanosoma species as the first species of the genus Eleotris composes the Nike fish schools in Paguyaman Bay and Gorontalo waters in general. Exploration of adult species and their distribution in the freshwaters of the Paguyaman River assumed to be the habitat of adult Nike fish should be performed to ensure the sustainability of Nike fish resources in the future. Although the adult species of Nike fish is an unvalued economic commodity, unfortunately the post larva stage when recruiting back into the river is often targeted by fishermen for consumption (Ellien et al. 2016; Roesma et al. 2020), including in Gorontalo waters. Identification of these species must be carried out continuously to prevent the loss of these fish species while catching along with commodity fishing. This research indicates many types of species constituents in Gorontalo waters may be collected when an extensive study is conducted later in the future, specifically in river estuarine locations that are not explored.

\section{ACKNOWLEDGEMENTS}

The authors express our deep gratitude to the Institute of Research and Community Service (LPPM) of the Gorontalo State University, Indonesia that has funded this research through the scheme of Penelitian Dasar (Basic Research) for the 2021 Fiscal Year. We also would like to thank Thomas Tammu, Adistya, and all parties for their technical assistance and contribution during the study.

\section{REFERENCES}

Aisyah S, Syarif AF. 2018. Morphometric and meristic characters of Selangat fish (Anodontostoma sp.) from Kelabat Bay and Tukak Strait, Bangka Belitung. Adv Eng Res 167: 13-16. DOI: 10.2991/icoma-18.2019.4. 
Batuwita S, Udugampala S, Edirisinghe U. 2017. On the occurrence of the black spine-cheek gudgeon Eleotris melanosoma Bleeker in $\mathrm{Sr}$ Lankan Waters, with comments on the green-backed guavina Bunaka gyrinoides (Bleeker) (Teleostei: Eleotridae). J Threat Taxa 9 (7): 10374-10379. DOI: 10.11609/jott.2915.9.7.10374-10379.

Bellagamba F, Velayutham D, Cozzi MC, Caprino F, Vasconi M, Busetto ML, Bagnato A, Moretti VM. 2015. Cytochrome oxidase-I sequence based studies of commercially available Pangasius hypophthalmus in Italy. Ital J Anim Sci 14 (3): 378-382. DOI: 10.4081/ijas.2015.3928.

Bingpeng X, Heshan L, Zhilan Z, Chunguang W, Yanguo W, Jianjun W 2018. DNA barcoding for identification of fish species in the Taiwan Strait. Plos One 13 (6): e0198109. DOI: 10.1371/journal.pone.0198109.

Djumanto, Devi MIP, Setyobudi E. 2013. Ichthyofauna distribution in downstream region of Opak River, Yogyakarta. Jurnal Iktiologi Indonesia 13 (2): 97-108. DOI: 10.32491/jii.v13i2.97

Ellien C, Werner U, Keith P. 2016. Morphological changes during the transition from freshwater to sea water in an amphidromous goby, Sicyopterus lagocephalus (Pallas 1770) (Teleostei). Ecol Freshw Fish 25: 48-59. DOI: 10.1111/eff.12190.

Elliott NG, Haskard K, Koslow JA. 1995. Morphometric analysis of orange roughy (Hoplostethus atalanticus) off the continental slope of southern Australia. J Fish Biol 46 (2): 202-220. DOI: 10.1111/j.10958649.1995.tb05962.x.

Gani A, Bakri AA, Adriany DT, Nurjirana N, Herjayanto M, Bungalim MI, Ndobe S, Burhanuddin AI. 2019. Identification of freshwater goby species from The Biak and Koyoan Rivers, Luwuk Banggai, Central Sulawesi. Spermonde 5 (2): 57-60. DOI: 10.20956/jiks.v5i2.8931.

Habibie SA, Djumanto, Rustadi. 2015. The use of otolith to determine age and spawning time of red devil Amphilophus labiatus (Günther, 1864) in Sermo Reservoir, Yogyakarta. Jurnal Iktiologi Indonesia 15 (2): 87-98. DOI: 10.32491/jii.v15i2.63. [Indonesian]

Habibie SA, Djumanto, Murwantoko. 2018. Polychromatic, sexua dimorphism and redescription species of red devil Amphilophus amarillo (Stauffer \& McKaye, 2002) in Sermo Reservoir, Yogyakarta. Jurnal Iktiologi Indonesia 18 (1): 69-86. DOI: 10.32491/jii.v18i1.375. [Indonesian]

Hadiaty RK, Sauri S. 2017. Freshwater fish of Enggano Island, Indonesia. Jurnal Iktiologi Indonesia 17 (3): 273-287. DOI: 10.32491/jii.v17i3.365. [Indonesian]

Hubert N, Kadarusman, Wibowo A, Busson F, Caruso D, Sulandari S, Nafiqoh N, Poiyaud L, Rüber L, Avarre JC, Herder F, Hanner R, Keith P, Hadiaty RK. 2015. DNA barcoding indonesian freshwater fishes: Challenges and prospects. DNA Barcodes 3: 144-169. DOI 10.1515/dna-2015-0018

Iida M, Kondo M, Tabouret H, Maeda K, Pécheyran C, Hagiwara A, Keith P, Tachihara K. 2017. Specific gravity and migratory patterns of amphidromous gobioid fish from Okinawa Island, Japan. J Exp Mar Biol Ecol 486: 160-169. DOI: 10.1016/j.jembe.2016.09.011.

Jeon HB, Choi SH, Suk HY. 2012. Exploring the utility of partia cytochrome c oxidase subunit 1 for DNA barcoding of gobies. Anim Syst Evol Divers 28 (4): 269-278. DOI: 10.5635/ASED.2012.28.4.269.

Keith P. 2003. Biology and ecology of amphidromous Gobiidae of the Indo-Pacific and the Caribbean regions. J Fish Biol 63: 831-847. DOI 10.1046/j.1095-8649.2003.00197.X.

Keith P, Hoareau TB, Lord C, Ah-Yane O, Gimonneau G, Robinet T, Valade P. 2008. Characterisation of post-larval to juvenile stages, metamorphosis and recruitment of an amphidromous goby, Sicyopterus lagocephalus (Pallas) (Teleostei: Gobiidae: Sicydiinae). Mar Freshw Res 59: 876-889. DOI: 10.1071/MF08116.

Keith P, Lord C, Busson F, Sauri S, Hubert N, Hadiaty RK. 2015. A new species of Sicyopterus (Gobiidae) from Indonesia. Cybium 39 (4) 243-248. DOI: 10.26028/cybium/2015-394-001

Kumar S, Stecher G, Li M, Knyaz C, Tamura K. 2018. MEGA X Molecular evolutionary genetics analysis across computing platforms. Mol Biol Evol 35: 1547-1549. DOI: 10.1093/molbev/msy096.

Lagarde R, Teichert N, Faivre L, Grondin H, Magalon H, Pirog A, Ponton D. 2017. Artificial daily fluctuations of river discharge affect the larval drift and survival of a tropical amphidromous goby. Ecol Freshw Fish 27 (3): 1-14. DOI: 10.1111/eff.12381.

Landau S, Everit BS. 2004. A Handbook of Statistical Analyses using SPSS. Chapman \& Hall/CRC, Washington DC.

Laskar BA, Kumar V, Kundu S, Tyagi K, Singha D, Charaborty R, Chatterjee S, Saha S. 2016. DNA barcoding of Gobiid fishes
(Perciformes: Gobiidae) from eastern and northeastern India with new record of a Gobionellinae species for the region. Mitochondrial DNA Part A: 1-4. DOI: 10.3109/24701394.2016.1143470.

Lejeune L, Tabouret H, Taillebois L, Monti D, Keith P. 2016. Larval traits of the Caribbean amphidromous goby Sicydium punctatum (Gobioidei: Sicydiinae) in Guadeloupe. Ecol Freshw Fish 25 (2): 272 280. DOI: 10.1111/eff.12208.

Linh NM, Thu PT, Quan NV, Chien PV, Ly DH, Nhan DV, Len DT. 2018. DNA barcoding application of mitochondrial COI gene to identify some fish species of family Gobiidae in Vietnam. J Mar Sci Tech-Japan 18 (4): 433-451. DOI: 10.15625/1859-3097/18/4/13662.

Lord C, Bellec L, Dettaï A, Bonillo C, Keith P. 2019. Does your lip stick? Evolutionary aspects of the mouth morphology of the Indo-Pacific clinging goby of the Sicyopterus genus (Teleostei: Gobioidei: Sicydiinae) based on mitogenome phylogeny. J Zool Syst Evol Res 00: 1-16. DOI: 10.1111/jzs.12291.

Maeda K, Tachihara K. 2005. Recruitment of amphidromous sleepers Eleotris acanthopoma, Eleotris melanosoma, and Eleotris fusca into the Teima River, Okinawa Island. Ichthyol Res 52: 325-335. DOI: 10.1007/s10228-005-0289-z.

Maeda K, Tachihara K. 2010. Diel and seasonal occurrence patterns of drifting fish larvae in the Teima Stream, Okinawa Island. Pac Sci 64 (2): 161-176. DOI: $10.2984 / 64.2 .161$

Maeda K, Mukai T, Tachihara K. 2011. Newly collected specimens of the sleeper Eleotris acanthopoma (Teleostei: Eleotridae) from French Polynesia indicate a wide and panmictic distribution in the West and South Pacific. Pac Sci 65 (2): 257-264. DOI: 10.2984/65.2.257.

McDowall RM. 2009. Early hatch: A strategy for safe downstream larval transport in amphidromous gobies. Rev Fish Biol Fish 19 (1): 1-9. DOI: $10.1007 / \mathrm{s} 11160-008-9085-\mathrm{y}$.

Mennesson MI, Tabouret H, Pécheyran C, Feunteun E, Keith P. 2015. Amphidromous life cycle of Eleotris fusca (Gobioidea: Eleotridae), a widespread species from the Indo-Pacific studied by otolith analysis. Cybium 39: 249-260. DOI: 10.26028/cybium/2015-394-002.

Mennesson MI, Maeda K, Keith P. 2019. Evolutionary aspects of cephalic Sensory papillae of the Indo-Pacific species of Eleotris (Teleostei: Eleotridae). Zool Scr 48 (5): 627-639. DOI: 10.1111/zsc.12366.

Mennesson MI, Keith P. 2020. Eleotris (Telostei: Eleotridae) of the Indian Ocean: An overview with the description of three new species. Cybium 44 (3): 185-203. DOI: 10.26028/cybium/2020-443-002.

Miesen FW, Droppelmann F, Hüllen S, Hadiaty RK, Herder F. 2016. An annotated checklist of the inland fishes of Sulawesi. Bonn Zool Bull 64 (2): 77-106.

Murdy EO, Hoese DF. 2002. Suborder Gobioidei. In: Carpenter KE (eds). FAO Species Identification Guide for Fishery Purposes, The Living Marine Resources of the Western Central Atlantic, Vol. 3: Bony Fishes Part 2 (Opistognathidae to Molidae), Sea Turtles and Marine Mammals. FAO, Rome.

Nurjirana, Afrisal M, Sufardin, Haris A, Burhanuddin AI. 2020. Diversity and distribution freshwater ichthyofaunal of West Sulawesi. IOP Conf Ser Earth Environ Sci 486: 012079. DOI: 10.1088/17551315/486/1/012079

Olii AH, Sahami FM, Hamzah SN, Pasisingi N. 2017. Preliminary findings on distribution pattern of larvae of nike fish (Awaous sp.) in the estuary of Bone River, Gorontalo Province, Indonesia. AACL Bioflux 10: 1110-1118

Olii AH, Sahami FM, Hamzah SN, Pasisingi N. 2019. Molecular approach to identify gobioid fishes, "Nike" and "Hundala" (local name), from Gorontalo Waters, Indonesia. Online J Biol Sci 19 (1): 51-56. DOI: 10.3844/ojbsci.2019.51.56.

Pasisingi N, Olii AH, Habibie SA. 2020a. Morphology and growth pattern of nike fish (Amphidromous goby larvae) in Gorontalo Waters, Indonesia. Tomini J Aquat Sci 1 (1): 1-7. DOI: 10.37905/tjas.v1i1.5622.

Pasisingi N, Habibie SA, Olii AH. 2020b. Are Awaous ocellaris and Belobranchus belobranchus the two species of Nike fish schools? Aceh J Anim Sci 5 (2): 87-91. DOI: 10.13170/ajas.5.2.16713.

Rodrigues MS, Morelli KA, Jansen AM. 2017. Cytochrome c oxidase subunit 1 gene as a DNA barcode for discriminating Trypanosoma cruzi DTUs and closely related species. Parasites Vectors 10: 488. DOI: 10.1186/s13071-017-2457-1.

Roesma DI, Tjong DH, Munir W, Aidil DR. 2018. New record species of Puntius (Pisces: Cyprinidae) from West Sumatra based on cytochrome oxidase 1 gene. Intl J Adv Sci Eng Inf Techno 8: 250256. DOI: $10.18517 /$ ijaseit.8.1.4170 
Roesma DI, Tjong DH, Aidil DR. 2020. Phylogenetic analysis of transparent gobies in three Sumatran lakes, inferred from mitochondrial cytochrome oxidase I (COI) gene. Biodiversitas 21 (1): 43-48. DOI: 10.13057/biodiv/d210107.

Sahami FM, Kepel RC, Olii AH, Pratasik SB. 2019a. Determination of morphological alteration based on molecular analysis and melanophore pattern of the migrating Nike fish in Gorontalo Bay, Indonesia. AACL Bioflux 12 (4): 1358-1365.

Sahami FM, Kepel RC, Olii AH, Pratasik SB. 2019b. What species make up the Nike fish assemblages at the macrotidal estuary in Gorontalo Bay, Indonesia? [version 1; peer review: 2 approved with $\begin{array}{llll}\text { reservation]. } & \text { F1000Research } & \text { 8: } 1654 . & \end{array}$ 10.12688/f1000research.19501.1.

Sahami FM, Kepel RC, Olii AH, Lasabuda R, Wantasen A, Habibie SA. 2020. Morphometric and genetic variations of species composers of nike fish assemblages in Gorontalo Bay Waters, Indonesia. Biodiversitas 21 (10): 4571-4581. DOI: 10.13057/biodiv/d211015.

Sahami FM, Habibie SA. 2020. Exploration of adult phase of nike fish to maintain its sustainability in Gorontalo Bay waters, Indonesia. AACL Bioflux 13 (5): 2859-2867.

Salam A, Sahami FM, Panigoro C. 2016. Nike (Awaous melanocephalus) fishery and mercury contamination in the estuary of Bone-Bolango River. Omni-Akuatika 12 (2): 130-136. DOI: 10.20884/1.oa.2016.12.2.121.

Sara L, Muskita WH, Astuti O, Safilu. 2016. The reproductive biology of blue swimming crab Portunus pelagicus in Southeast Sulawesi Waters, Indonesia. AACL Bioflux 9 (5): 1101-1112.

Subchan W, Susilo VE, Khairiyah Y, Wahyudewantoro G, Ariyunita S, Rohman A. 2020. The diversity of freshwater fish in Sanenrejo and Wonoasri River Resorts from Meru Betiri National Park. J Phys Conf Ser 1832: 012009. DOI: 10.1088/1742-6596/1832/1/012009.

Taillebois L, Maeda K, Vigne S, Keith P. 2012. Pelagic larval duration of three amphidromous Sicydiinae gobies (Teleostei: Gobioidei) including widespread and endemic species. Ecol Freshw Fish 21 (4): 1-8. DOI: 10.1111/j.1600-0633.2012.00575.x.

Taillebois L, Castelin M, Lord C, Chabarria R, Dettaï A, Keith P. 2014. New sicydiinae phylogeny (Teleostei: Gobioidei) inferred from mitochondrial and nuclear genes: Insights on systematics and ancestral areas. Mol Phylogenet Evol 70: 260-271. DOI: 10.1016/j.ympev.2013.09.026.

Thuesen PA, Ebner BC, Larson H, Keith P, Silcock RM, Prince J, Russell DJ. 2011. Amphidromy links a newly documented fish community of continental Australian streams, to oceanic islands of the West Pacific. Plos One 6 (10): e26685. DOI: 10.1371/journal.pone.0026685.

Tweedley JR, Bird DJ, Potter IC, Gill HS, Miller§ PJ, O’Donovan G, Tjakrawidjaja AH. 2013. Species compositions and ecology of the riverine ichthyofaunas on two Sulawesian islands in the biodiversity hotspot of Wallacea. J Fish Biol 82 (6): 1916-1950. DOI: 10.1111/jfb.12121.

Viswambharan D, Pavan-Kumar A, Singh DP, Jaiswar AK, Chakraborty SK, Nair JR, Lakra WS. 2013. DNA barcoding of gobiid fishes (Perciformes, Gobioidei). Mitochondrial DNA 26 (1): 15-19. DOI: 10.3109/19401736.2013.834438.

Wang ZD, Liao J, Huang CQ, Long SS, Zhang S, Guo YS, Liu L, Liu CW. 2017. Significant genetic differentiation of Gobiopterus lacustris, a newly recorded transparent goby in China. Mitochondrial DNA Part A: 1-7. DOI: 10.1080/24701394.2017.1357712.

Ward RD, Zemlak TS, Innes BH, Last PR, Hebert PDN. 2005. DNA barcoding Australia's fish species. Philos Trans R Soc Lond B Biol Sci 360 (1462): 1847-1857. DOI: 10.1098/rstb.2005.1716.

Wolok T, Fachrussyah ZC, Yantu I. 2019. Technical and economic analysis of catching equipment totaluo in nike fishing (Awaous melanocephalus) in Gorontalo City. Jambura Sci Manag 1 (2): 65-71. DOI: $10.37479 /$ jsm.v1i2.2520.

Yamasaki N, Kondo M, Maeda K, Tachihara K. 2011. Reproductive biology of three amphidromous gobies, Sicyopterus japonicus, Awaous melanocephalus, and Stenogobius sp., on Okinawa Island. Cybium 35 (4): 345-360.

Yulianto D, Indra I, Batubara AS, Fadli N, Nur FM, Rizal S, Azizah MNS, Muchlisin ZA. 2020. Morphometrics and genetics variations of mullets (Pisces: Mugilidae) from Aceh waters, Indonesia. Biodiversitas 21 (8): 3422-3430. DOI: 10.13057/biodiv/d210802. 